\title{
MENINGKATKAN HASIL BELAJAR MATEIMATIKA SISWA TENTANG PENGURANGAN BILANGAN BULAT MENGGUNAAN MEDIA KARTU BILANGAN
}

Improving Students Mathematics Learning Outcomes About Subtracting Integers Using Number Card Media

Lici

SDN I4 Palangka, Palangkaraya, Kalimantan Tengah, Indonesia.

\section{ARTIKEL INFO}

Diterima

Agustus 2021

Dipublikasi

September 2021

*e-mail :

lici6919@gmail.com

\section{ABSTRAK}

Penelitian ini dilatarbelakangi pembelajaran Matematika di Sekolah Dasar, pembelajaran yang menggunakan metode yang tepat dapat membangkitkan minat dan motivasi siswa untuk belajar, sehingga anggapan matematika adalah pelajaran yang sulit dapat terhapuskan selanjutnya hasil belajar siswa pun akan meningkat.. Adapun tujuan dari penelitian ini yaitu untuk mengetahui bagaimana hasil belajar matematika siswa tentang pengurangan bilangan bulat di kelas I SDN I4 Palangka setelah mengikuti pembelajaran matematika dengan penggunaan media kartu bilangan dan meningkatkan kemampuan guru dalam mengimplementasikan model pembelajaran matematika dengan penggunaan media kartu bilangan yang berorientasi pada upaya meningkatkan hasil belajar siswa.

Metode yang digunakan dalam penelitian ini adalah Penelitian Tindakan Kelas. Penelitian dilaksanakan dalam dua siklus, satu siklus terdiri atas perencanaan pembelajaran, Hasil penelitian menunjukkan bahwa hasil belajar siswa dalam pembelajaran matematika dengan menggunakan model pembelajaran matematika dengan penggunaan media kartu bilangan mengalami peningkatan tiap siklusnya. Rekapitulasi hasil pembelajaran siklus I dengan nilai rata-rata 58,46 dan siklus II dengan nilai rata-rata 66,92 . Maka hasil penelitian ini menunjukkan penggunaan model pembelajaran matematika dengan penggunaan media kartu bilangan dapat meningkatkan hasil belajar siswa dalam pembelajaran matematika.

Kata Kunci : Pembelajaran Matematika, Hasil belajar siswa, Media Kartu Bilangan.

\section{ABSTRACT}

This research is motivated by learning Mathematics in Elementary Schools, learning using the right method can arouse students' interest and motivation to learn, so that the assumption that mathematics is a difficult subject can be erased, then student learning outcomes will increase. The purpose of this research is to find out how the results of students' mathematics learning about subtracting integers in class I SDN I4 Palangka after participating in mathematics lessons using number card media and improving the teacher's ability to implement mathematics learning models using number card media that are oriented towards improving student learning outcomes.

The method used in this research is Classroom Action Research. The research was carried out in two cycles, one cycle consisting of lesson planning. The results showed that student learning outcomes in learning mathematics by using the mathematics learning model with the use of number card media increased each cycle. Recapitulation of learning outcomes in the first cycle with an average value of 58.46 and the second cycle with an average value of 66.92. So the results of this study indicate the use of a mathematical learning model with the use of number card media can improve student learning outcomes in learning mathematics.

Keywords : Mathematics Learning, Student learning outcomes, Number Card Media 


\section{Jurnal Pendidikan Teknologi Informasi}

\section{PENDAHULUAN}

Rendahnya prestasi akademik dan ketidakmampuan siswa dalam menyelesaikan matematika merupakan hal yang sangat serius dan dianggap sebagai kebutuhan yang mendesak untuk ditangani di sekolah.

Beberapa faktor yang menyebabkan permasalahan di atas adalah:

I. Kegiatan pembelajaran tradisional dalam pembelajaran guru masih berkisar pada kegiatan penjelasan, dengan contoh dan siswa melalui latihan untuk mengajukan pertanyaan seperti menulis.

2. Guru perlu memasukkan banyak materi karena mereka fokus pada pendidikan hanya berdasarkan pencapaian tujuan kurikulum dan pada akhirnya mengabaikan pencapaian perolehan siswa.

Upaya peningkatan mutu pendidikan harus dilakukan dengan cakupan yang mendalam tentang etika, karakter, kepribadian, pengetahuan, keterampilan, seni, olahraga, dan perilaku. Matematika merupakan salah satu mata pelajaran yang diajarkan di sekolah dasar. Matematika saat ini merupakan bagian dari ilmu-ilmu dasar yang berkembang sangat cepat baik dari segi materi dan kegunaannya maupun strategi pembelajarannya.

Matematika adalah mata pelajaran yang koheren dan abstrak berdasarkan fakta. Materi ajar matematika bukanlah yang pertama kali dipelajari siswa di sekolah dasar. Kemampuan siswa dalam belajar matematika berkembang sejalan dengan kemampuan kognitifnya, dan dapat dipastikan bahwa ideide matematika yang diketahui dikembangkan secara sistematis dalam bentuk pembelajaran yang terencana.

Uraian diatas mengungkapkan bahwa Matematika sangat penting, namun di sisi lain prestasi siswa dalam matematika masih jauh dari yang diinginkan. Pada kenyataannya pembelajaran tidak maksimal karena metode pembelajaran dan alat peraga yang digunakan tidak sesuai dengan kebutuhan. la menegaskan UU Pendidikan No. 1989-2, berkaitan dengan undang-undang no. 20 tahun 2003 tentang pasal 13 sistem pendidikan nasional, yang menyatakan: "Menjadi warga negara yang kreatif, mandiri, demokratis, dan bertanggung jawab".

Siswa SD mengalami kesulitan dalam memahami konsep pengurangan. Sehingga dibutuhkan kesabaran, kejujuran, perhatian, kesabaran, profesionalisme guru dan pengabdian yang setinggi-tingginya untuk mengajarkannya. Pemahaman siswa terhadap konsep reduksi relatif rendah. $\mathrm{Hal}$ ini ditunjukkan dengan rendahnya nilai ulangan harian pengurangan bilangan bulat. Bagi siswa sekolah dasar, pengurangan bukanlah hal yang mudah atau sulit karena mereka tidak mengenal bilangan dengan baik.

Solusi lain yang dapat mengatasi masalah di atas adalah dengan menggunakan dudukan kartu digital. Dukungan belajar ini memungkinkan siswa untuk memahami dan menjelaskan matematika melalui kegiatan pembelajaran. Hakikat reduksi pertama yang ditaburkan dalam diri siswa/pelajar adalah "reduksi", yaitu bahasa sehari-hari yang sering didengar siswa (peserta didik) di tingkat dasar. Contohnya dalam pengurangan misalnya: $\mathrm{Di}$ dalam kantong tersedia 15 permen siswa disuruh mengurangi permen itu didalam kantong sebanyak 4 permen, dengan alat peraga yaitu permen.

Jumlah permen dalam kantong 15 dikurangi 4 permen, maka $15-4=I I \quad D i$ awal junior school anak akan mengenal aspek "Kurang" dari operasi pengurangan ini terjadi ketika ingin mengurangi sebagian permen diambil dari dalam kantong permen itu. Jadi apabila mengurangan sebuah bilangan dengan bilangan lain, artinya kita mengurangi bilangan sebanyak bilangan yang dikurangi. Pengertian serta bahasan matematika itu sangat beragam . keanekaragaman definisinya itu sendiri satu sama lain saling melengkapi . Kurikulum 


\section{Jurnal Pendidikan Teknologi Informasi}

Berbasis Kompetensi (Depdiknas, 2003 : 2 ) menuliskan tentang matematika yaitu :

Matematika adalah materi pendidikan dengan tujuan abstrak dan dibangun dari proses penalaran deduktif. Dengan kata lain, kebenaran suatu konsep diperoleh sebagai hasil logis dari kebenaran yang diterima sebelumnya, sehingga hubungan antar konsep matematika sangat kuat dan jelas.

Darmansyah (2006:13) mengemukakan bahwa hasil belajar adalah hasil penilaian kemampuan siswa yang didefinisikan secara numerik. Dari komentar di atas, dapat disimpulkan bahwa hasil belajar adalah hasil penilaian hasil kemampuan siswa setelah melalui proses pembelajaran. Cece Rahmat (Zainal Abidin, 2004: I) menyatakan bahwa hasil belajar adalah: Penentuan penggunaan angka dalam suatu nilai tes atau proses evaluasi berdasarkan aturan tertentu, yaitu daya terima peserta didik dalam belajar setelah mempelajari suatu mata pelajaran tertentu.

Ada berbagai bentuk media yang dapat digunakan untuk belajar matematika di tingkat dasar. Jenis-jenis kendaraan tersebut adalah: (A) Objek awal di lingkungan siswa, (b) Dashboard, (c) Simbol numerik, (d) Sumbu, (e) Model jalan datar, (f) Pondasi Dash, (g) Model konstruksi ruang. Menurut Wina Sanjaya (2006: 17I), penunjang yang digunakan harus sesuai dengan bahan ajar.

\section{METODOLOGI PENELITIAN}

Metode yang digunakan dalam penelitian ini adalah Penelitian Tindakan Kelas (PTK). PTK bermula dari permasalahan yang dihadapi guru. Temuannya dapat digunakan secara langsung untuk meningkatkan kualitas pendidikan dan pembelajaran di kelas, atau untuk meningkatkan kualitas pembelajaran. Pelaksanaan dapat dimulai dengan analisis situasi, perencanaan tindakan, refleksi dan evaluasi tindakan. Proses ini dapat diulang sampai kualitas yang diinginkan tercapai. PTK merupakan salah satu upaya guru dengan orientasi dan tujuan yang jelas, terutama membantu siswa mencapai hasil belajar yang memuaskan. PT memiliki ciri-ciri yang membedakannya dengan jenis penelitian lainnya. Singkatnya, masalah yang diselidiki muncul dalam bentuk masalah praktik pembelajaran kelas sehari-hari yang dihadapi guru. Tindakan tertentu diperlukan untuk memperbaiki masalah ini. Atau meningkatkan kualitas pembelajaran di kelas.

\section{HASIL DAN PEMBAHASAN}

Penelitian tindakan kelas yang dilaksanakan di kelas I pada mata pelajaran matematika, dalam penggunaan media kartu bilangan menekankan pada pengembangan hasil belajar serta strategi pembelajaran yang lebih tepat pada mata pelajaran matematika, Dengan media tersebut mampu berpartisipasi aktif dalam aktivitas matematisasi dengan memanfaatkan kemampuan matematika informal ke arah pemahaman matematika formal. Dengan demikian diharapkan akan tercipta kondisi belajar yang bermakna (meaningfull learning) dan dapat meningkatkan kemampuan siswa dalam memahami konsepkonsep matematika serta tercapainya tujuan pembelajaran yang telah ditetapkan dalam kurikulum matematika.

Siklus I

Sebagai langkah awal penelitian, dilakukan kegiatan observasi atau pengamatan terhadap pelaksanaan kegiatan belajar mengajar di kelas I. Pembelajaran dilakukan seperti biasanya, guru memberikan dan menjelaskan materi yang akan dipelajari pada hari itu sambil melakukan tanya jawab mengenai beberapa masalah operasi hitung yang terjadi dalam kehidupan sehari-hari, misalnya jumlah permen dalam kantong 15 dikurangi 4 permen, dengan menggunakan sifat komutatif soal tersebut diselesaikan dengan cara : 15 - 4 (mengapa?). Kemudian guru menerangkan dengan menggunakan 


\section{Jurnal Pendidikan Teknologi Informasi}

media kartu bilangan untuk menjawab soal tersebut, dan selanjutnya siswa menemukan bahwa $15-4=11$.

Pada langkah selanjutnya, siswa akan dibagi menjadi beberapa kelompok. Setiap kelompok terdiri dari empat siswa dan guru mengajukan pertanyaan tentang kondisi mahasiswa baru. Ini harus didiskusikan dengan kelompok. Dengan mengangkat masalah secara kelompok, siswa akan saling berinteraksi dan berkolaborasi secara optimal. Selama ini, guru mengelola dan membimbing kegiatan diskusi.

Jika ada yang belum dipahami oleh siswa, guru tidak akan menjelaskan secara langsung, tetapi akan membimbing dan menciptakan kondisi bagi siswa untuk berdiskusi. Dalam kegiatan diskusi, siswa mendemonstrasikan pengurangan secara berkelompok tanpa teknik peminjaman. Siswa menunjukkan antusiasme yang besar untuk langkah ini dalam diskusi kelompok. Hal ini dimungkinkan karena peserta didik klasik disegarkan dengan suasana diskusi kelompok. Pertukaran antar siswa dalam kelompok juga berlangsung sesuai rencana. Siswa SMP dan SMA ingin bisa bertanya kepada senior lainnya tanpa kehilangan rasa percaya diri. Di sisi lain, siswa berprestasi merasa senang karena dapat membantu teman sebayanya.

Selama siklus pertama, pengamat mengamati semua kegiatan yang terjadi baik dalam kegiatan guru maupun siswa. Pengamat kemudian mengevaluasi beberapa kegiatan yang teridentifikasi pada lembar observasi. Pada akhir siklus pembelajaran pertama, siswa mengikuti tes penilaian.

Tujuan pelaksanaan tes ini adalah untuk mengetahui daya serap siswa dan daya serap klasikal, sehingga dapat dilihat sejauh mana pemahaman dan hasil belajar siswa terhadap materi yang dilaksanakan pada pembelajaran di siklus I.

Tabel I

Daftar Nilai Tes Evaluasi Siklus I

\begin{tabular}{|c|l|c|}
\hline No. & \multicolumn{1}{|c|}{ Nama Siswa } & Nilai \\
\hline \hline 1 & Anum C,S,Apratama & 70 \\
\hline 2 & Apriel Aldiansyah & 50 \\
\hline 3 & Bayu Setiawan & 40 \\
\hline 4 & Daud Frebiansyah & 60 \\
\hline 5 & Fanny Nurul Awaliyah R & 70 \\
\hline 6 & Ica Dwi Anggia & 70 \\
\hline 7 & Imelda Putri Febrian & 70 \\
\hline 8 & Kamaludin & 40 \\
\hline 9 & Muhamad Sonaji & 50 \\
\hline 10 & Revina Mustika Labang & 50 \\
\hline II & Rizky Aditya & 80 \\
\hline 12 & Salwa.D.Alia & 50 \\
\hline 13 & Selvia Zulistia & 60 \\
\hline \multicolumn{2}{|c|}{ Jumlah } & 760 \\
\hline \multicolumn{2}{|c|}{ Rata-Rata } & 58,46 \\
\hline
\end{tabular}

Dari Tabel I dapat dilihat bahwa siswa yang telah mencapai ketuntasan (nilai minimal 60 ) berjumlah 7 orang atau $54 \%$ dan yang belum mencapai ketuntasan (nilai kurang dari 60) berjumlah 6 orang atau 46\%. Rata-rata yang diperoleh kelas yaitu 58,46. Setelah pembelajaran siklus I selesai dilaksanakan, peneliti dan observer mengadakan refleksi untuk mengidentifikasi permasalahan yang timbul selama pembelajaran siklus I, sekaligus mengadakan rencana perbaikan yang akan dilakukan pada pembelajaran siklus I

Siklus II

Pada awal pembelajaran guru mengecek kehadiran siswa untuk mempersiapkan kesiapan siswa dalam mengikuti pembelajaran di siklus II ini dan untuk memotivasi siswa, guru mengumumkan hasil tes evaluasi siklus I yaitu tentang pengurangan yang telah dipelajari. Guru juga menjelaskan kembali dari beberapa konsep yang masih kurang dipahami dan dimengerti siswa pada siklus sebelumnya.

Guru mengajak siswa melakukan kegiatan pemecahan masalah matematika tentang pengurangan dengan media Kartu

Pada tahap selanjutnya, guru meminta siswa untuk mengidentifikasi hasil 


\section{Jurnal Pendidikan Teknologi Informasi}

pengurangan beban yang diberikan guru. Hal ini memungkinkan siswa untuk benar-benar memahami dan memahami materi. Pada langkah selanjutnya, siswa diajak duduk berkelompok, seperti pada siklus belajar pertama. Setiap kelompok terdiri dari 4 orang. Kemudian guru memberikan setiap kelompok lembar kerja dan setiap kelompok berdiskusi dan bekerja. Alokasi waktu untuk setiap kelompok dibatasi maksimal 20 menit. Dari apa yang kita lihat dalam diskusi kelompok pada siklus II, siswa tampak lebih terorganisir dan lebih aktif dalam berkomunikasi dengan teman sebayanya dibandingkan pada siklus sebelumnya.

$\mathrm{Di}$ akhir diskusi kelompok, guru mengevaluasi pekerjaan masing-masing kelompok dan guru meminta perwakilan setiap kelompok untuk mengajukan pertanyaan di depan kelas berdasarkan jawaban yang diberikan selama diskusi kelompok. Guru dan siswa kemudian menyimpulkan dengan materi yang mereka pelajari hari itu. Semua kegiatan yang berlangsung selama pembelajaran siklus II diamati oleh observer dan hasilnya dilaporkan dalam bentuk lembar observasi.

Kegiatan akhir siklus II adalah melengkapi penilaian siklus II. Tujuan penilaian adalah untuk mengetahui tingkat daya serap dan pemahaman siswa terhadap materi siklus II. Pada siklus II ini peneliti didampingi oleh observer yang mengamati seluruh aktivitas siswa dan guru selama pembelajaran siklus II.

Tabel II

Data Nilai Hasil Test Kelas I Siklus II

\begin{tabular}{|c|l|c|}
\hline No & \multicolumn{1}{|c|}{ Nama Siswa } & Nilai \\
\hline \hline I & Anum C,S,Apratama & 80 \\
\hline 2 & Apriel Aldiansyah & 60 \\
\hline 3 & Bayu Setiawan & 50 \\
\hline 4 & Daud Frebiansyah & 70 \\
\hline 5 & Fanny Nurul Awaliyah R & 80 \\
\hline 6 & Ica Dwi Anggia & 70 \\
\hline 7 & Imelda Putri Febrian & 70 \\
\hline
\end{tabular}

\begin{tabular}{|c|l|c|}
\hline 8 & Kamaludin & 60 \\
\hline 9 & Muhamad Sonaji & 60 \\
\hline 10 & Revina Mustika Labang & 60 \\
\hline II & Rizky Aditya & 80 \\
\hline 12 & Salwa.D.Alia & 60 \\
\hline 13 & Selvia Zulistia & 70 \\
\hline \hline \multicolumn{2}{|c|}{ Jumlah } & 870 \\
\hline \multicolumn{2}{|c|}{ Rata - Rata } & 66,92 \\
\hline
\end{tabular}

Dari Tabel II dapat dilihat bahwa siswa yang telah mencapai ketuntasan (nilai minimal 60) berjumlah 12 orang atau $92 \%$ dan yang belum mencapai ketuntasan (nilai kurang dari 60) berjumlah I orang atau $8 \%$. Rata-rata yang diperoleh kelas yaitu 66,92 . Pada siklus II ini telah mengalami peningkatan dibandingkan dengan siklus I. Pemahaman siswa pada pembelajaran matematika dengan menggunakan pendekatan matematika realistik setiap siklus tidak selalu sama. Tetapi di siklus ke II pada penelitian ini motivasi belajar dan pemahaman siswa mengalami peningkatan walaupun tidak signifikan. Hal ini dibuktikan dengan nilai yang mengalami peningkatan dari siklus I ke siklus II. Walaupun masih ada beberapa siswa yang masih kurang memahami dari soal pemecahan masalah dan menganggapnya rumit soal tersebut, hal ini menandakan bahwa belajar menggunakan metode realistik pada operasi hitung penjumlahan dan pengurangan bilangan cacah sangat cocok untuk diterapkan kepada siswa dalam pembelajaran. Dan cara guru membagi siswa dalam kelompok juga sangat berpengaruh kepada keaktifan anak dalam belajar, anak jadi bisa bertanya pada teman sebaya sehingga anak yang tidak mengerti dapat terbantu sehingga lebih cepat memahami materi melalui kontruksi yang mereka bangun bersama teman-temannya. Respon siswa secara keseluruhan terhadap pembelajaran dapat dilihat dari hasil wawancara.

Dari hasil wawancara dapat dilihat bahwa siswa dari level rendah, sedang dan tinggi pada umumnya merasa senang belajar matematika melalui penggunaan media kartu

Lici 


\section{Jurnal Pendidikan Teknologi Informasi}

bilangan, karena menurut mereka pembelajaran seperti ini dapat lebih mudah dipahami dan belajar jadi lebih aktif. Dengan demikian dapat disimpulkan bahwa respon siswa terhadap pembelajaran operasi hitung bilangan melalui penggunaan media kartu bilangan adalah bagus atau positif.

\section{KESIMPULAN}

Berdasarkan seluruh kegiatan penelitian yang dibuat dari mulai Perencanaan pembelajaran, Pelaksanaan pembelajaran Pembagian kelompok, Lembar kerja siswa, Pengamatan pembelajaran, Refleksi pembelajaran, Penilayan hasilkerja siswa, Peneliti dapat merumuskan beberapa kesimpulan mengenai pembelajaran Matemateka tentang pengurangan bilangan bulat melalui penggunakan media kartu bilangan pada kelas I SD Negeri I4 Palangka Kota Palangka Raya. Tentang pengurangan bilangan bulat dengan media kartu bilangan sebagai berikut :

Perencanaan pembelajaran tentang Pengurangan Bilangan Bulat Menggunaan Media Kartu Bilangan untuk meningkatkan hasil belajar siswa dalam pembelajaran matematika dibuat sebaik mungkin oleh peneliti mengacu pada kurikulum 2006, serta dipersiapkan juga media pembelajaran alat evaluasi dan lembarkerja siswa, Guru akan memulai Kegiatan inti dengan memberikan permasalahan matematika kepada setiap kelompok untuk dipecahkan bersama. Lihat RPP Siklus I dan II Pelaksanaan pembelajaran dengan menggunakan media kartu bilangan sesuai rencana yang telah dipersiapkan pada pelaksanaan siklus I ketuntasan belajar siswa mencapai $92 \%$ dan pada siklus II. Pada siklus I masih banyak kendala yang dirasakan oleh peneliti saat proses belajar mengajar berlangsung, peneliti juga merasakan proses pembelajaran masih kurang epektif. Berdasarkan pengamatan pada siklus I, maka penulis melakukan refleksi agar proses pembelajaran berjalan secara optimal. Usaha

yang dilakukan oleh peneliti berhasil baik, hal tersebut dikarenakan pada siklus II proses pembelajaran menunjukkan hasil presentasi nilai meningkat.

Aktifitas siswa dengan menggunakan media kartu bilangan berdasarkan hasil pengamatan observer penunjukkan peningkatan meskipun tidak begitu tinggi . Hasil Belajar Siswa Setelah mengikuti pembelajaran dengan media kartu bilangan bagi siswa adalah hal yang menyenangkan. Hal ini terlihat pada perolehan rata- rata skor nilai yang meningkat pada pelaksanaan siklus I sampai pelak sanaan siklus II.

Pada siklus I diperoleh rata-rata skor nilai siswa $58 \%$ dan meningkat pada pelaksanaan siklus II dengan nilai rata-rata yang diperoleh $67 \%$, dengan nilai KKM yang telah di tentukan 60. Pada siklus I terdapat 7 siswa yang tuntas dan pada siklus II terdapat 12 siswa yang tuntas.

\section{DAFTAR PUSTAKA}

Bahari Samsudin (2004) Kamus Matematika Bergambar Untuk SD, Jakarta: Gramedia Widia Sarana Indonesia.

Anisa, Rizki Nur dan Agung Riadin. 2017. Upaya Meningkatkan Hasil Belajar Siswa pada Mata Pelajaran Matematika dengan menggunakan Model Pembelajaran Kooperatif Tipe Teams Games Tournament (TGT) pada SDN 2 Selat Dalam Kuala Kapuas Tahun Pelajaran 2016/2017. Tunas: Jurnal Pendidikan Guru Sekolah Dasar. 3: I (53-6I).

Departemen Pendidikan dan Kebudayaan (1994) Matematika I Mari Berhitung, Jakarta: Depdiknas.

Departemen Pendidikan Nasional (2006) Permendiknas No. 32 Tahun 2006 Tentang Standar Isi untuk Satuan Pendidikan Dasar dan Menengah, Jakarta: Depdiknas.

Edward D. Zaccaro (2005) Challenge Math For The Elementary and Middle School Student (School Edition), USA: Hictory Grove Press. 


\section{Jurnal Pendidikan Teknologi Informasi}

Permadi Ade Salahudin dan Repitae Repitae. 2018. Upaya Meningkatkan Hasil Belajar Matematika Menggunakan Model Pembelajaran Berbasis Dengan Media Konkret Pada Peserta Didik Kelas IV SDN-3 Telangkah Tahun Pelajaran 2016/2017. Pedagogik: Jurnal Pendidikan. 13:2(23-28).

Putra, Chandra Anugrah, M Andi Setiawan, M Jailani dan Ade S Permadi. 2019. Upaya Meningkatkan Keterampilan Menulis Karangan Deskripsi Menggunakan Model Explicit Instruction Berbasis Teknologi Multimedia. Jurnal Seminar Internasional Riksa Bahasa.

Riadin Agung dan Muhammad Jailani. 2020. Differences in Increasing an Economic Learning Outcomes by Applying the Cooperative Model of NHT (Numbered Head Together) and IOC (Inside Outside Circle) Models in Participants. Differences. I I:2.

Tim KKG Matematika (2005). Matematika untuk SD/MI Kelas I, Malang: Dinas Pendidikan Kota Malang. 